\title{
A new phenothiazine-based selective visual and fluorescent sensor for cyanide
}

\author{
Fatimah A. M. Al-Zahrani ${ }^{1}$, Reda M. El-Shishtawy ${ }^{2,3^{*}}$, Abdullah M. Asiri ${ }^{2,4}$, Amerah M. Al-Soliemy ${ }^{5}$, \\ Khloud Abu Mellah', Nahed S. E. Ahmed ${ }^{3}$ and Abdesslem Jedidi
}

\begin{abstract}
A new donor-т-acceptor derived from phenothiazine, namely 2-(2-((10-hexyl-10H-phenothiazin-3-yl)methylene)3-oxo-2,3-dihydroinden-1-ylidene) malononitrile (PTZON) was synthesized and fully characterized, and its potential as a fluorescent sensor for cyanide anion was investigated. The PTZON showed a visible absorption band at $564 \mathrm{~nm}$ corresponds to an intramolecular charge transfer (ICT) and an emission band at $589 \mathrm{~nm}$ in $\mathrm{CH}_{3} \mathrm{CN} / \mathrm{H}_{2} \mathrm{O}$. The results of cyanide anion titration revealed ratiometric changes in both absorption and fluorescence spectra as a result of the nucleophilic addition of cyanide anion via Michael addition. The optical studies, FT-IR spectra, NMR, high-resolution mass, and DFT calculations confirmed the sensing mechanism. The selectivity of PTZON as a cyanide anion fluorescent sensor was proved in mixed solvent solutions, and the sensitivity was as low as $0.011 \mu \mathrm{M}$, which is far lower than the value allowed by the United States Environmental Protection Agency for drinking water $(1.9 \mu \mathrm{M})$. Also, the detection limit of PTZON was assessed to be $3.39 \mu \mathrm{M}$ by the spectrophotometric method. The binding stoichiometry between PTZON and cyanide anion was found to be 1:1 as evidenced by mass spectra. TLC silica-coated plates test strips demonstrated the fluorescent detection of cyanide anion.
\end{abstract}

Keywords: Visual and fluorescent sensor, Phenothiazine, Cyanide, Nucleophilic addition, Detection limit, Intramolecular charge transfer

\section{Introduction}

Cyanide anion is notoriously toxic and deadly affect human beings because of its ability to bind to the active site of cytochrome oxidase and inhibit cellular respiration [1]. Cyanide anion is being involved in several industries such as metal plating, textile manufacture, and herbicides, and therefore, the awareness has to be taken not to load the environment by the effluents of these industries $[2,3]$. At the point when cyanide enters the body by oral, inward breath, it applies its severe impacts by complexing with ferric iron molecules in metalloenzymes, bringing about histotoxic anoxia through restraint of cytochrome c oxidase $[4,5]$. The WHO (world health organization)

\footnotetext{
*Correspondence: relshishtawy@kau.edu.sa; elshishtawy@hotmail.com ${ }^{2}$ Chemistry Department, Faculty of Science, King Abdulaziz University, P.O. Box 80203, Jeddah 21589, Saudi Arabia
}

Full list of author information is available at the end of the article declared that the highest allowable level of cyanide anion concentration in the drinking water is $1.9 \mu \mathrm{M}$ [6]. It has been reported that as little as $0.5-3.5 \mathrm{mg}$ of cyanide per kilogram of human body weight can lead to death $[7,8]$. Thus, monitoring and detection of cyanide anions are of great interest. Numerous techniques inclusive titrimetric [9], voltammetric [10], chromatographic strategies [11], electrochemical gadgets [12, 13], colorimetric [14-16] and fluorometric [17-25] have been used to estimate cyanide anions. Of the above-mentioned techniques, the fluorescence technique is considered the best due to its high sensitivity, fast response, low cost, and simple detection procedure [24-27]. In this interest, the development of fluorescent chemosensor for cyanide anions in aqueous solutions have been of growing interest [27-33]. The high nucleophilicity of cyanide anion inspired organic chemists to design and synthesize several chemosensors that 
function via nucleophilic addition mechanism [34-39]. Donor- $\pi$-acceptor $(\mathrm{D}-\pi-\mathrm{A})$ chromophores are known to have high tinctorial strength owing to the presence of an intramolecular charge transfer (ICT) band. The ICT band is easily tuned by varying the strength of the donor or acceptor or both. Such an interesting structural feature makes these compounds of great interest in various fields [40-45]. In this interest, the phenothiazine heterocyclic ring is a good electron donor in building chromophores of donor- $\pi$-acceptor type suitable as a fluorescent sensor, nonlinear optical material, and dye-sensitized solar cells [27, 46-48].

Here we present a new chemosensor derived from phenothiazine of donor- $\pi$-acceptor skeleton amenable for structural and optical changes upon cyanide addition with fast response. These changes are a consequence of breaking the ICT that exists between donor- $\pi$-acceptor. The selectivity and sensitivity of PTZON were investigated using UV-vis absorption and fluorescence. Additionally, the sensing mechanism was confirmed by DFT calculations, FT-IR, NMR and mass spectroscopies.

\section{Experimental General}

All solvents and reagents were of the highest purity available, purchased from Sigma-Aldrich Company and used as received. ${ }^{1} \mathrm{H}$ and ${ }^{13} \mathrm{C}$ NMR spectra were recorded in $\mathrm{CDCl}_{3}$ and DMSO- $\mathrm{d}_{6}$ solution on a Bruker Avance 600 and $400 \mathrm{MHz}$ spectrometer. Infrared spectra were performed on PerkinElmer spectra 100 FTIR spectrometer. Mass spectroscopy was performed using Agilent GC 7000 mass spectrometers. UV absorption spectra were determined in different solvents on Shimadzu UV-VIS Spectrophotometer. Fluorescence spectra were recorded on PerkinElmer LS 55 Fluorescence Spectrometer.

\section{Synthesis and characterization}

2-(2-((10-hexyl-10H-phenothiazin-3-yl)

methylene)-3-oxo-2,3-dihydroinden-1-ylidene)malononitrile (PTZON)

A mixture of 2 [49] (3 mmol) and 3-dicyanovinylindan1-one $(6 \mathrm{mmol})$ in basic ethanol solution $(7 \mathrm{ml})$ was stirred at room temperature overnight, filtered off and crystallization from cyclohexane to afford $80 \%$ yield. $\mathrm{M}$. p. $89-90{ }^{\circ} \mathrm{C} ;{ }^{1} \mathrm{H}$ NMR $\left(600 \mathrm{MHz}, \mathrm{DMSO}-\mathrm{d}_{6}\right) \delta 0.84(\mathrm{t}$, $\left.3 \mathrm{H}, \mathrm{CH}_{3}\right), 1.25\left(\mathrm{~m}, 4 \mathrm{H}, \mathrm{CH}_{2}\right), 1.27\left(\mathrm{~m}, 2 \mathrm{H}, \mathrm{CH}_{2}\right), 1.70(\mathrm{~m}$, $\left.2 \mathrm{H}, \mathrm{CH}_{2}\right), 3.96\left(\mathrm{t}, 2 \mathrm{H}, \mathrm{CH}_{2}-\mathrm{N}\right), 7.02(\mathrm{t}, 2 \mathrm{H}, \mathrm{Ar}-\mathrm{H}), 7.09$ (d, $2 \mathrm{H}, \mathrm{Ar}-\mathrm{H}), 7.17$ (m, 4H, Ar-H), 7.24 (m, 2H, Ar-H), 7.60 (s, $\mathrm{H}$, vinylic proton), $7.73(\mathrm{~d}, 1 \mathrm{H}, \mathrm{Ar}-\mathrm{H}) \cdot{ }^{13} \mathrm{C}$ NMR $\left(125 \mathrm{MHz}, \mathrm{DMSO}-\mathrm{d}_{6}\right) \delta 14.19,22.81,26.73,26.98,27.14$, 31.59, 48.52, 70.52, 114.56, 114.84, 116.15, 124.22, 124.25, $125.34,126.66,127.77,133.55,134.80,135.37,136.67$, 137.62, 139.91, 146.54, 150.69, 162.66, ESI-MS m/z
$[\mathrm{M}]^{+}$calc 487.61 found 486 ., IR $v / \mathrm{cm}^{-1}$ : $\mathrm{C}-\mathrm{H}$ aliphatic 2925, 2851, CN 2214, C=O 1739, C=C 1694.

\section{General spectroscopic procedures Method}

A solution of PTZON $\left(2 \times 10^{-5} \mathrm{M}\right)$ in acetonitrilewater (90:10) was titrated with increments of aqueous $\mathrm{KCN}\left(2 \times 10^{-3} \mathrm{M}\right)$ and were monitored by UV-visible and fluorescence methods. Titration experiments were carried out in $10-\mathrm{mm}$ quartz cell at room temperature. $\left(\lambda_{\mathrm{ex}}=500 \mathrm{~nm}, \lambda_{\mathrm{em}}=588 \mathrm{~nm}\right)$.

\section{Selectivity}

The selectivity experiment was done by monitoring the fluorescence intensity changes of PTZON $\left(2 \times 10^{-5} \mathrm{M}\right)$ in acetonitrile-water (90:10) at $588 \mathrm{~nm}\left(\lambda_{\mathrm{ex}}=500 \mathrm{~nm}\right)$ upon addition of various anions at the concentrations indicated below the figure.

\section{Detection limit}

The following equation calculated the limit of detection $(\mathbf{L O D}) ; \mathbf{L O D}=\mathbf{3 S} / \boldsymbol{\rho}$, where $\mathbf{S}$ is the standard deviation of blank measurements (10 runs), $\boldsymbol{\rho}$, is the slope between intensity versus sample concentration.

\section{Computational details}

Geometries of PTZON and PTZON-CN ${ }^{-}$were optimized in the vacuum through Density Functional Theory (DFT) via the spin-restricted Kohn-Sham formalism and the hybrid B3LYP functional $[50,51]$ using the valence double zeta basis set 6-31G(d) [52]. In all cases, frequency calculations were performed in order to confirm the nature of the stationary points (minima with no imaginary frequency). The UV-Vis parameters (maximum wavelength, electronic excitation energies, and oscillator strengths) of the studied compounds have been calculated with the time-dependent density functional theory (TD-B3LYP) at the $6-31 \mathrm{G}(\mathrm{d})$ level of theory $[53,54]$ in order to evaluate the sensing effect made by $\mathrm{CN}^{-}$ion. All the detailed calculations were carried out through the facilities provided by the Gaussian09 package [55].

\section{Results and discussion}

Synthesis of PTZON

As shown in Scheme 1, PTZON was synthesized by the Knoevenagel condensation of 10-hexyl-10H-phenothiazine-3-carbaldehyde and 3-dicyanovinylindan-1-one. The molecular structure of the PTZON was confirmed by FTIR, ${ }^{1} \mathrm{H}$ NMR, ${ }^{13} \mathrm{C}$ NMR, and mass spectra.

\section{UV-vis absorption and fluorescence properties}

UV-vis absorption and fluorescence spectra of PTZON in acetonitrile-water (90:10) are presented in Fig. 1 to 
<smiles>CCCCCN1c2ccccc2Sc2ccccc21</smiles>

1

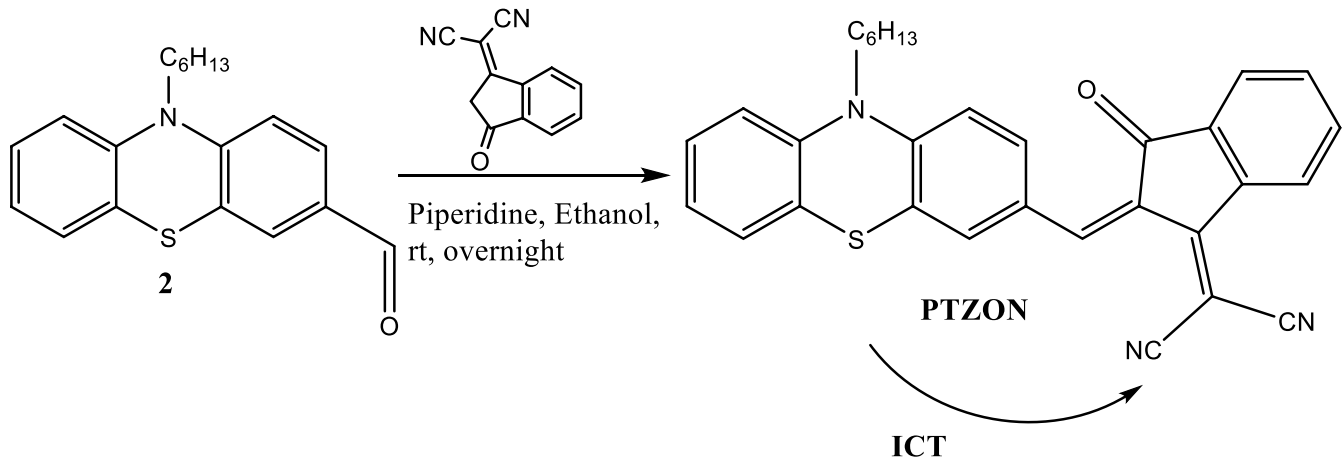

ICT

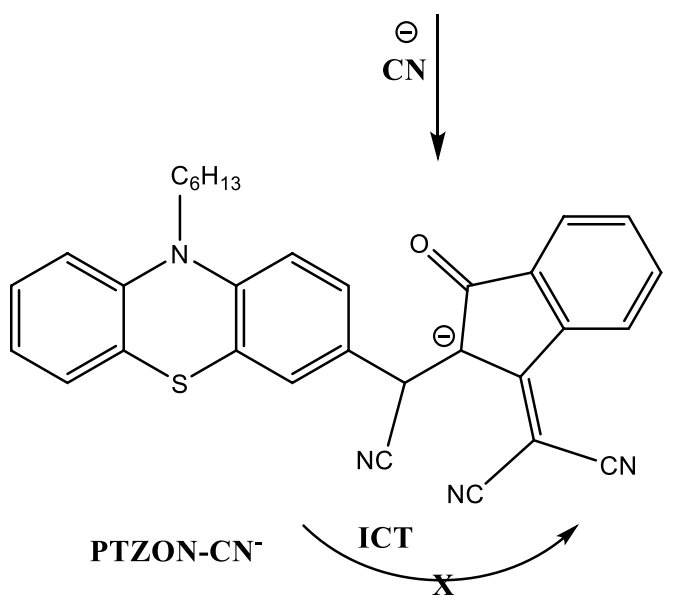

Scheme 1 Synthesis of PTZON and the sensing mechanism

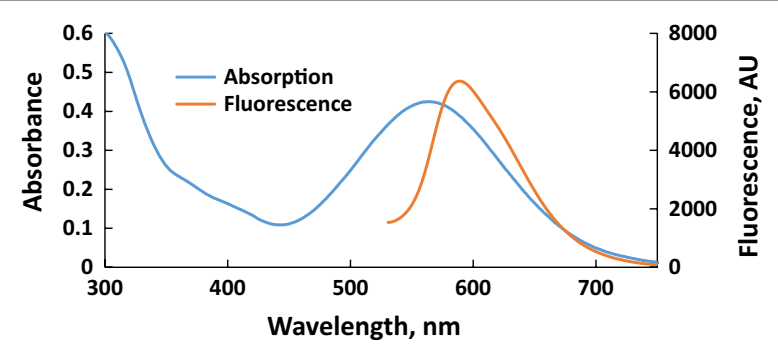

Fig. 1 Absorption and fluorescence spectra of PTZON $\left(2 \times 10^{-5} \mathrm{M}\right)$ in acetonitrile-water (90:10)

reveal the maximum wavelength of absorption and fluorescence at 564 and $589 \mathrm{~nm}$, respectively. The absorption band at $564 \mathrm{~nm}$ is due the ICT presents in the molecule with a molar extinction coefficient about $2.1 \times 10^{4} \mathrm{M}^{-1} \mathrm{~cm}^{-1}$.

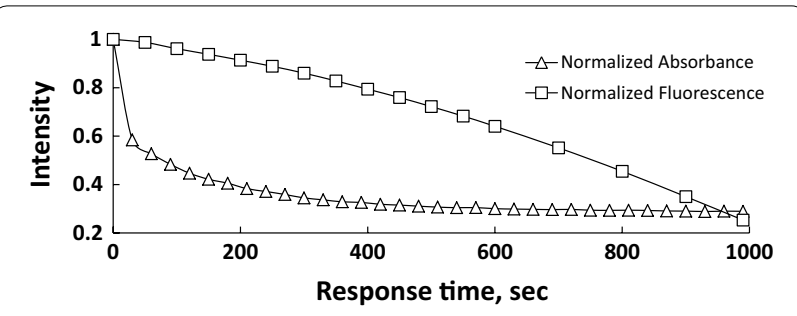

Fig. 2 Response time for the detection of cyanide anion in acetonitrile-water (90:10)

Response time shown in Fig. 2 for both UV-visible and fluorescence indicates that the response is fast, and about 3 min was sufficient time to reach the plateau of change, and therefore, $3 \mathrm{~min}$ was considered as the response time through the present study. The result of cyanide anion titration, as shown in Figs. 3, 4, 5, 6, concluded the 


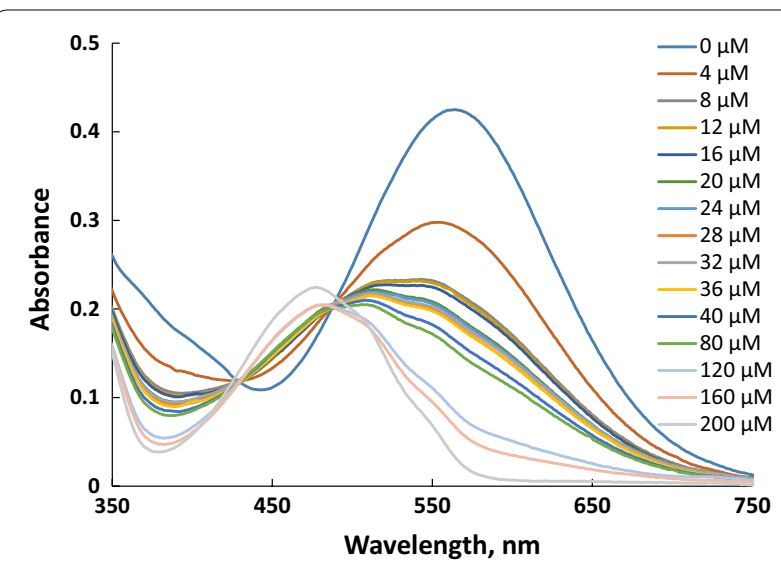

Fig. 3 Absorption spectra of PTZON $\left(2 \times 10^{-5} \mathrm{M}\right)$ upon the addition of cyanide anion at different concentration in acetonitrile-water (90:10)

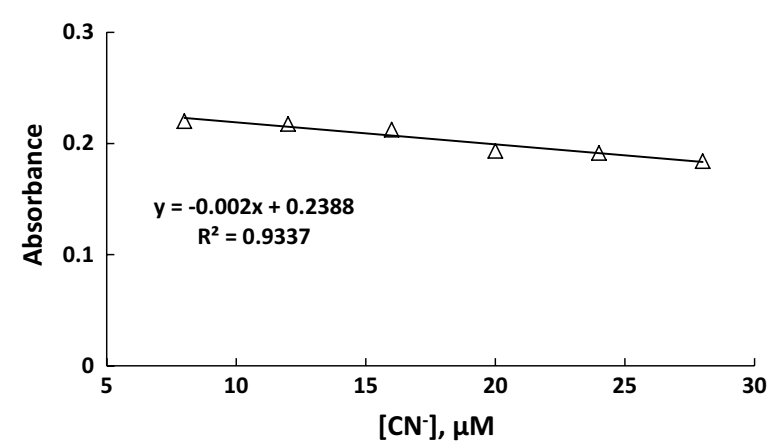

Fig. 4 Absorption intensity calibration curve of PTZON $\left(2 \times 10^{-5} \mathrm{M}\right)$ as a function of cyanide anion concentration in acetonitrile-water $(90: 10)$

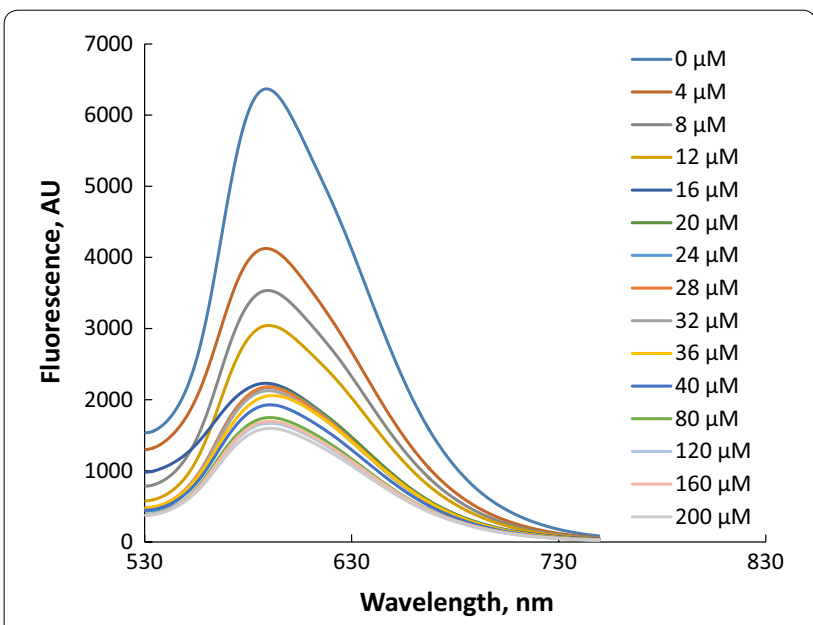

Fig. 5 Fluorescence spectra of PTZON $\left(2 \times 10^{-5} \mathrm{M}\right)$ upon the addition of cyanide anion at different concentration in acetonitrilewater (90:10). The fluorescence intensity was measured at $25^{\circ} \mathrm{C}$ $\left(\lambda_{\mathrm{ex}}=500 \mathrm{~nm}, \lambda_{\mathrm{em}}=588 \mathrm{~nm}\right)$

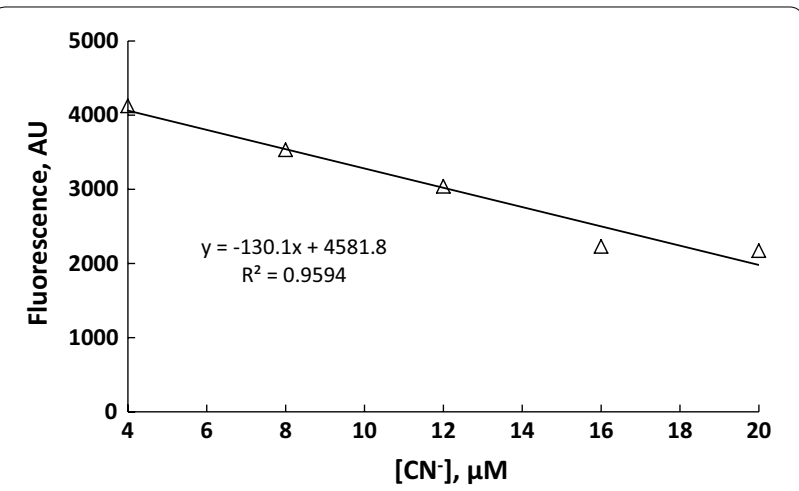

Fig. 6 Fluorescence intensity calibration curve of PTZON $\left(2 \times 10^{-5}\right.$ $\mathrm{M})$ as a function of cyanide anion concentration in acetonitrile-water $(90: 10)$

value of detection limit (LOD) to be 3.39 and $0.011 \mu \mathrm{M}$ by spectrophotometric and spectrofluorophotometric methods, respectively.

\section{Selectivity studies}

The selectivity of a chemosensor is an essential property for its possible application. Therefore, it was desired to investigate the selectivity of PTZON for cyanide anion detection in the presence of other anions. For this purpose, the fluorescence of PTZON solution alone, after being mixed with different anions of ten equiv., and after being mixed with different anions in the presence of cyanide anion in $5+5$ equiv. in $\mathrm{CH}_{3} \mathrm{CN} / \mathrm{H}_{2} \mathrm{O}$ solutions was followed after $3 \mathrm{~min}$ of response time. Interestingly, PTZON revealed high selectivity toward $\mathrm{CN}^{-}$than other anions, as shown in the figure. Although the other anions were used in large excess (10 equiv.) compared with cyanide anion (5 equiv.) yet the fluorescence of PTZON was slightly changed compared with the huge change made by cyanide anion. Also, the test of interference anions confirmed that the huge change observed was due to the selectively of PTZON toward cyanide anion. Figures 7, 8 and 9 show the selectivity of PTZON.

\section{Sensing mechanism}

The sensing mechanism was thought to be via Michael addition reaction of cyanide anion on $\beta$-vinylic carbon and to prove this mechanism; the high-resolution mass spectra of PTZON before and after cyanide anion addition was made. As shown in Fig. 10 the mass of PTZON (A) $\mathrm{m} / \mathrm{z}$ : calcd for $\mathrm{C}_{31} \mathrm{H}_{25} \mathrm{~N}_{3} \mathrm{OS}$ : $487.17[\mathrm{M}]^{+}$that found: $486.0[\mathrm{M}-\mathrm{H}]^{+}$has become after cyanide addition (B): $531.19\left[\mathrm{M}+\mathrm{CN}+\mathrm{H}_{2} \mathrm{O}\right]^{+}$, indicating that the addition is 1:1 stoichiometry of PTZON and cyanide anion.

On the other hand, the FTIR tool was also used to confirm the structure after cyanide anion addition on 


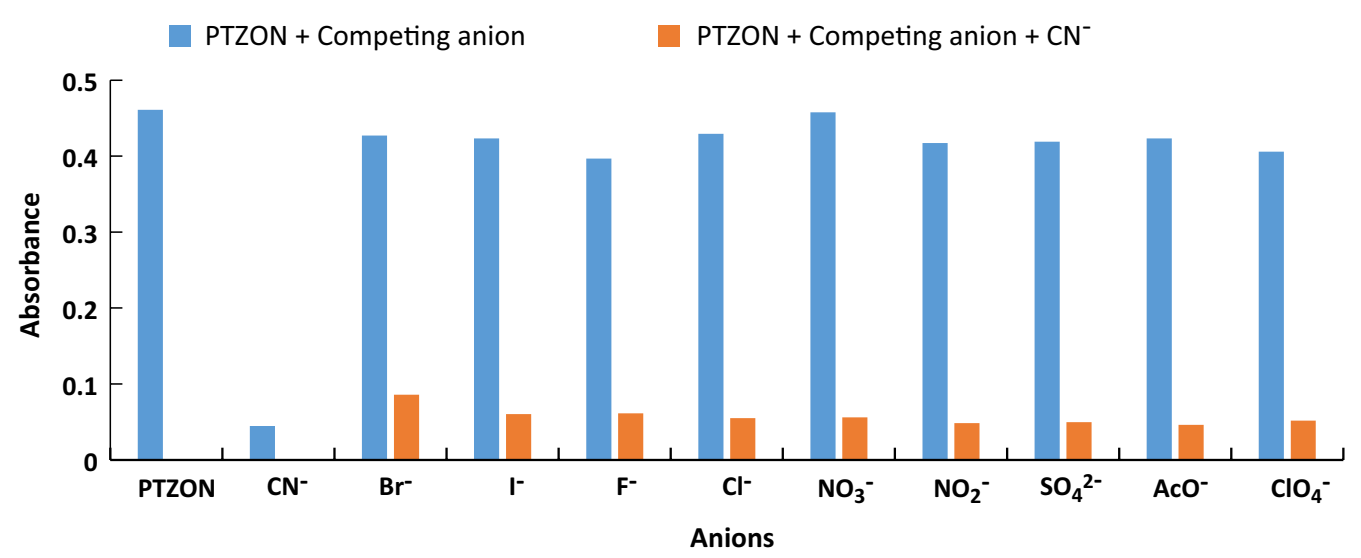

Fig. 7 The absorbance changes of PTZON $\left(2 \times 10^{-5} \mathrm{M}\right)$ in acetonitrile-water (90:10) in the presence of competing anions

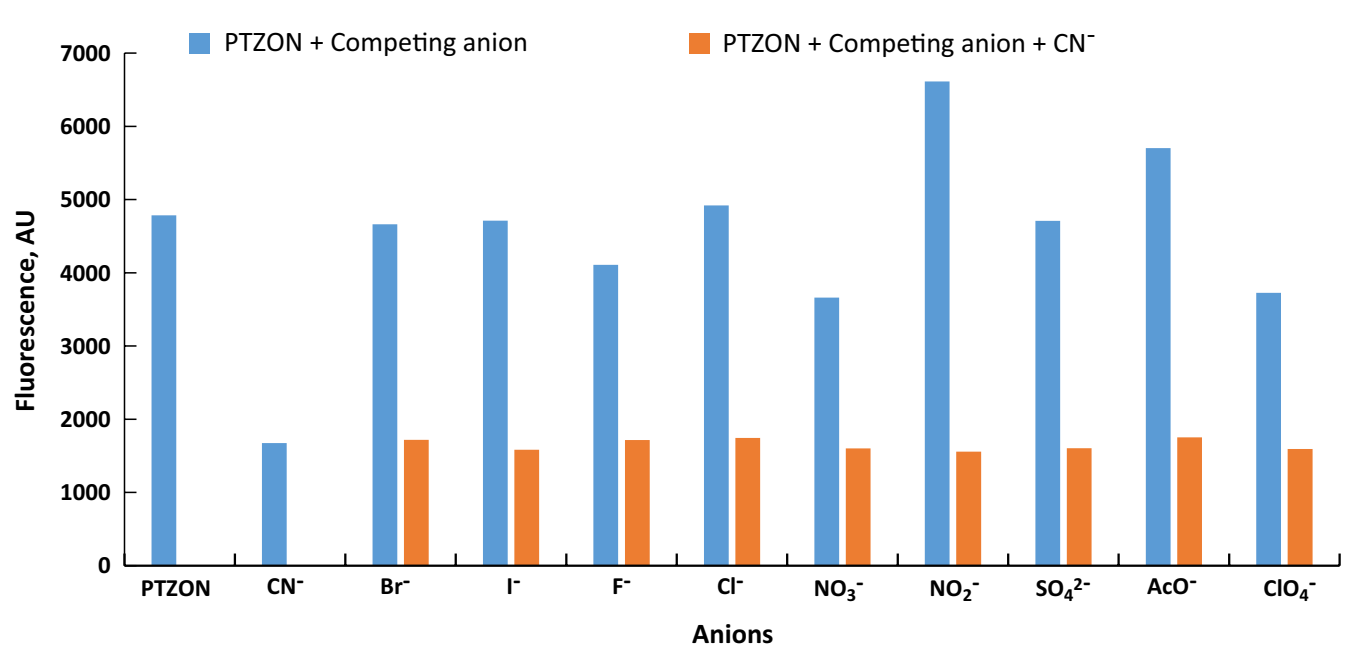

Fig. 8 The fluorescence intensity changes of PTZON $\left(2 \times 10^{-5} \mathrm{M}\right)$ in acetonitrile-water $(90: 10)$ in the presence of competing anions

PTZON. The most striking difference, as shown in Fig. 11 is the disappearance of a sharp peak at $1706 \mathrm{~cm}^{-1}$ due to $\mathrm{C}=\mathrm{O}$ present in PTZON before cyanide anion addition and the appearance of a broad peak at $1600 \mathrm{~cm}^{-1}$ due to hydrogen-bonded $\mathrm{C}=\mathrm{O}$ after cyanide anion addition. Additionally, the sharp peak that appears at $2200 \mathrm{~cm}^{-1}$ due to $\mathrm{CN}$ present in PTZON has become shifted to a lower frequency to appear at $2214 \mathrm{~cm}^{-1}$ with the appearance of another $\mathrm{CN}$ peak at $2179 \mathrm{~cm}^{-1}$ after cyanide anion addition.

\section{DFT studies}

Computational study of the PTZON before and after cyanide anion addition would further confirm the sensing mechanism. For this purpose, geometry optimization of both forms, followed by energy computation, was made using the computational details mentioned in the experimental section.

\section{Geometrical analysis}

PTZON structure is originally a flat structure with phenothiazine and indanone moieties. The substitution of the two carbon atoms in the para position of the middle ring in the phenothiazine ring by $\mathrm{N}$ and $\mathrm{S}$ atoms has generated a butterfly-like structure (Fig. 12a). We have checked the stability of this structure by frequency calculations, and no negative frequency means the structure is a low energy structure. We have added cyanide at the level of the trigonal carbon atom linking the phenothiazine and the indanone moieties (sp2 hybridization). After addition, the structure becomes tetragonal 

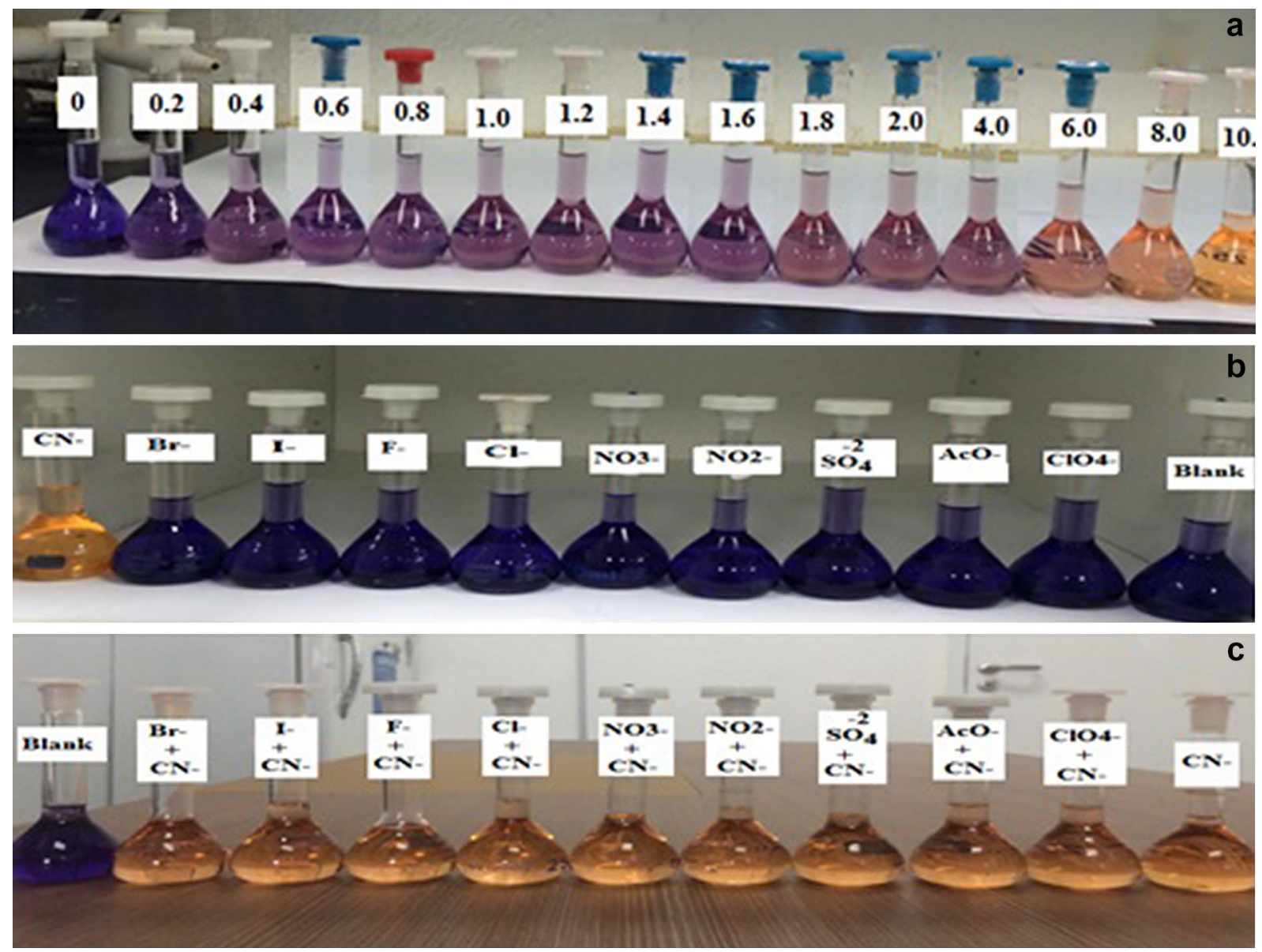

Fig. 9 The color changes upon gradual addition of different equiv. of cyanide anion (A) upon addition of 10 equiv. of different anions (B) and upon mixing 10 equiv. of cyanide anion and another competing anion (5 equiv. +5 equiv. each) (C). $\mathbf{A}$ Image of $\mathrm{CN}^{-}$responsive PTZON (from left to right: $0_{-10}^{-10}$ equiv.); $\mathbf{B}$ in the presence of 10 equiv of different anions (from left, $\mathrm{CN}^{-}, \mathrm{Br}^{-}, \mathrm{I}^{-}, \mathrm{F}^{-}, \mathrm{Cl}^{-}, \mathrm{NO}_{3}^{-}, \mathrm{NO}_{2}^{-}, \mathrm{SO}_{4}^{2-}, \mathrm{AcO}^{-}, \mathrm{ClO}_{4}^{-}, \mathrm{blank}^{2}$; $\mathbf{c}$ in the presence of 5 equiv. of $\mathrm{CN}^{-}$and 5 equiv. of different anions (from left, blank, $\mathrm{Br}^{-}, \mathrm{I}^{-}, \mathrm{F}^{-}, \mathrm{Cl}^{-}, \mathrm{NO}_{3}^{-}, \mathrm{NO}_{2}^{-}, \mathrm{SO}_{4}{ }^{2-}, \mathrm{AcO}^{-}, \mathrm{ClO}_{4}^{-}, \mathrm{CN}^{-}$)

at the same point, and the carbon goes for $\mathrm{sp}^{3}$ hybridization with a negative charge at the neighboring atom (see Fig. 12b).

\section{Vibrational analysis}

The two structures showed that $\mathrm{C}=\mathrm{O}$ vibrate at $1774 \mathrm{~cm}^{-1}$, for PTZON, which is reduced in the presence of $\mathrm{CN}^{-}$to reach $1723 \mathrm{~cm}^{-1}\left(\mathrm{PTZON}-\mathrm{CN}^{-}\right)$. The same behavior happened for the cyanide groups actually present in the initial structure (PTZON) with a frequency $2314-2333 \mathrm{~cm}^{-1}$ that goes to $2268-2298 \mathrm{~cm}^{-1}$ with one additional peak at $2350 \mathrm{~cm}^{-1}$ for the added $\mathrm{CN}^{-}$in PTZON-CN ${ }^{-}$(Table 1). The frontier molecular orbitals (FMOs) are represented mainly by the Highest Occupied Molecular Orbitals (HOMOs) and the Lowest Unoccupied Molecular Orbitals (LUMOs). Figure 13 shows the FMOs of the unbound and CN-bound PTZON simulated using the B3LYP/6-31G(d) level of theory.

\section{Charge transfer and UV-visible analysis}

The electron density in HOMO is mainly distributed on the phenothiazine ring, and the electron density in LUMO is distributed on the indanone moiety. This indicates the possible charge transfer from phenothiazine (donor) to the indanone moiety (acceptor). PTZON shows a strong absorption band at $581 \mathrm{~nm}$, which corresponds to the charge transfer band. As expected, all the HUMO and LUMO energy levels were raised after the formation of PTZON-CN ${ }^{-}$adduct, and the energy bandgap has increased from 2.44 to $3.04 \mathrm{eV}$ (Fig. 14). This increment in the energy gap value implies the breakage of $\pi$-conjugation between phenothiazine and indanone moieties. Thus the ICT process was stopped. This is consistent with the experimental observation with the complete disappearance of ICT band at $588 \mathrm{~nm}$ when PTZON-CN ${ }^{-}$adduct is formed. UV-vis spectra originate from $\pi \rightarrow \pi^{*}$ and $n \rightarrow \pi^{*}$ electronic transitions in $\pi$-conjugated organic compounds [56]. Table 2 lists 


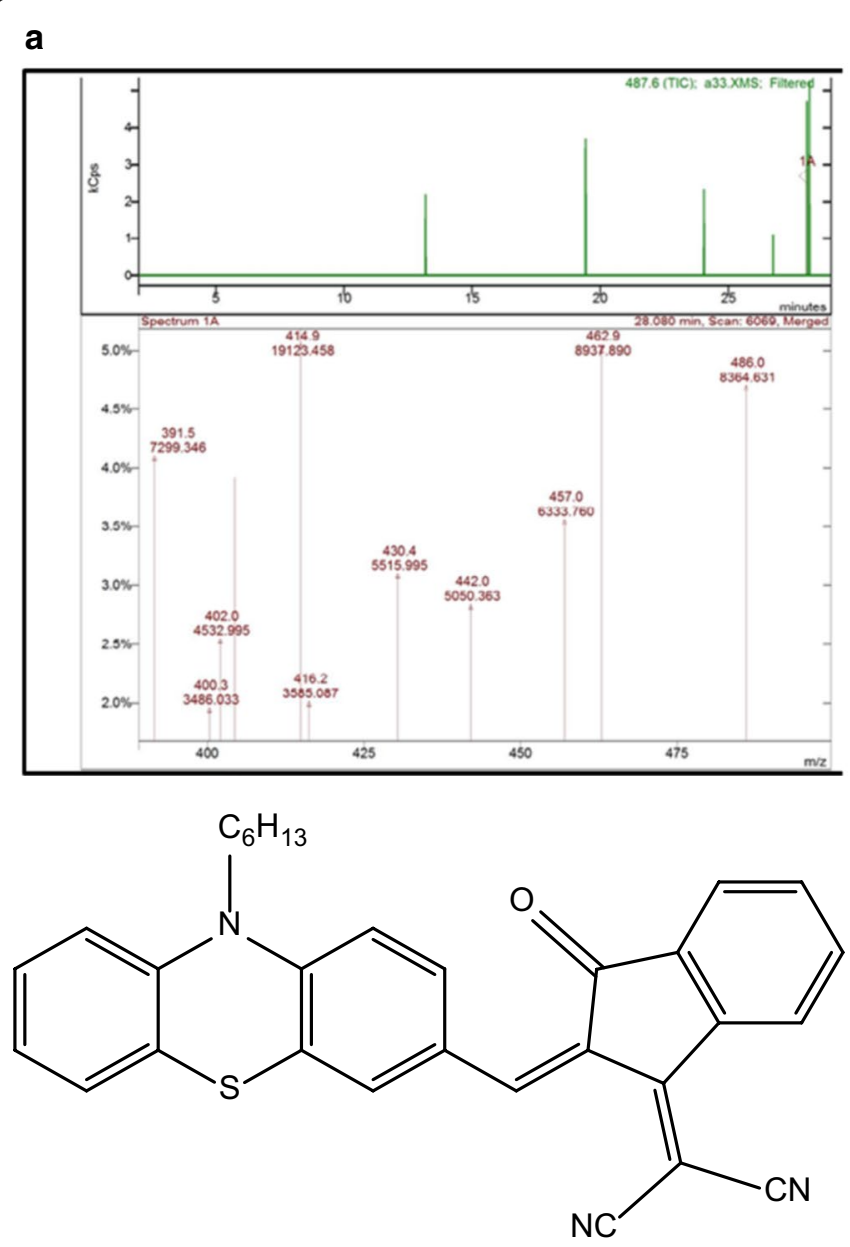

b
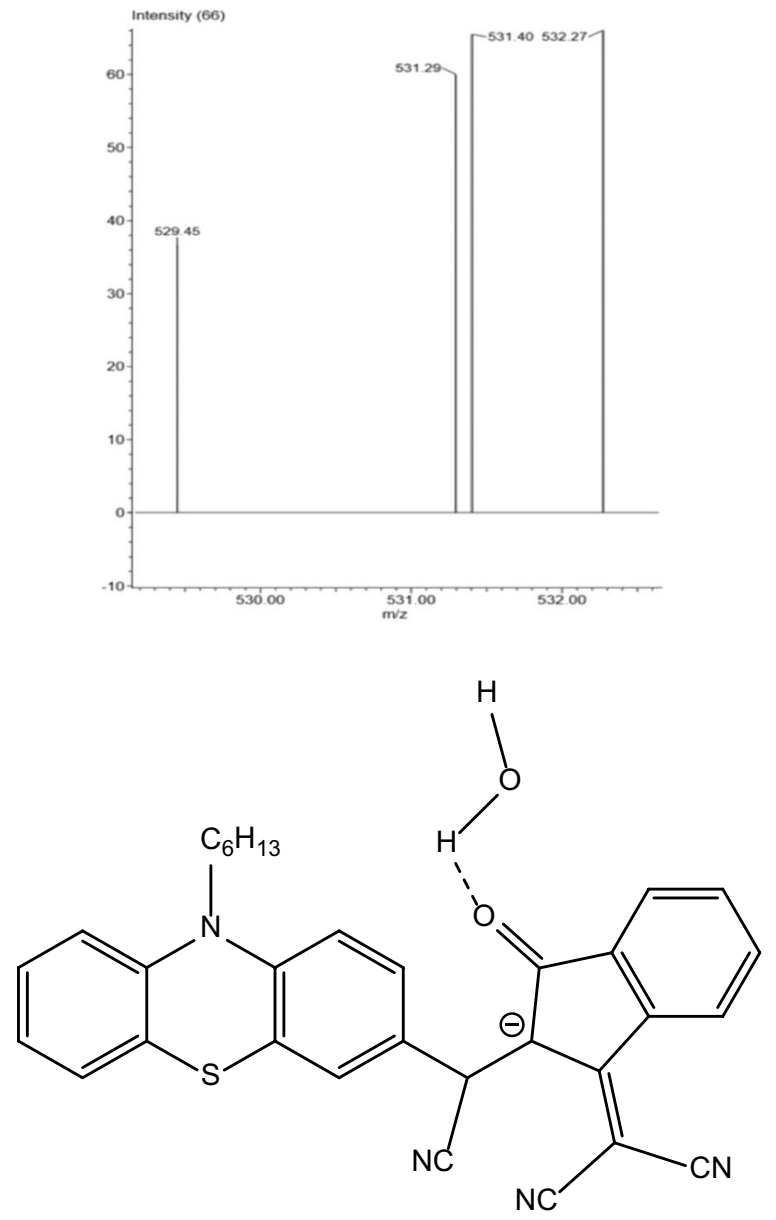

Fig. 10 LC-MS of PTZON before (a) and after addition of $\mathrm{CN}^{-}(\mathbf{b})$

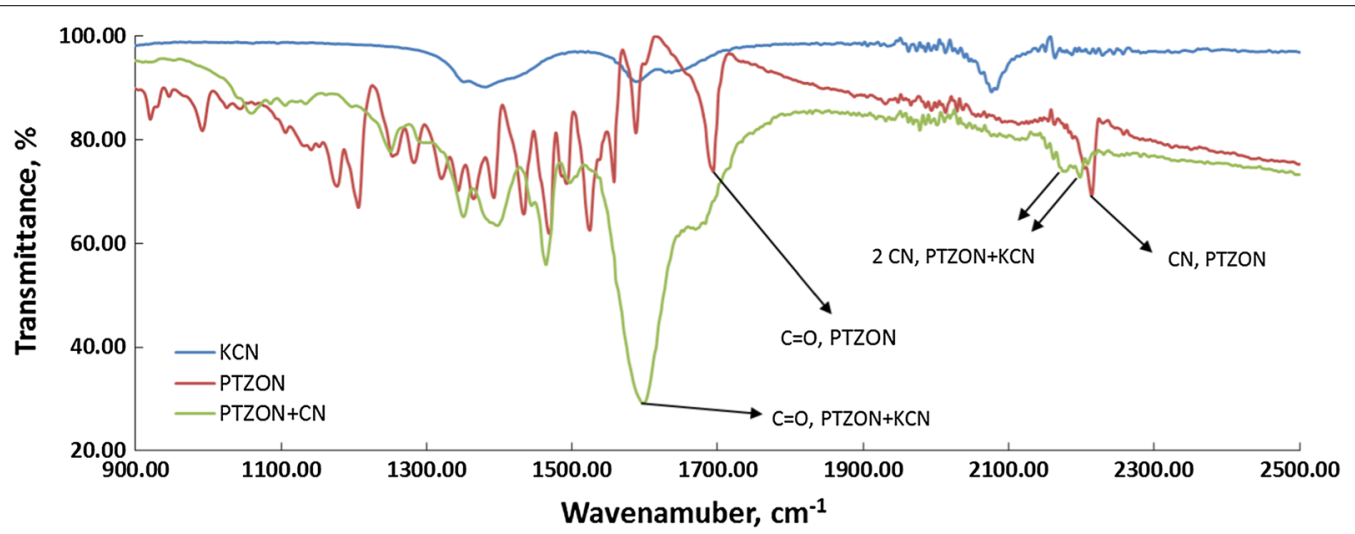

Fig. 11 FTIR of PTZON in absence and presence of cyanide anion 

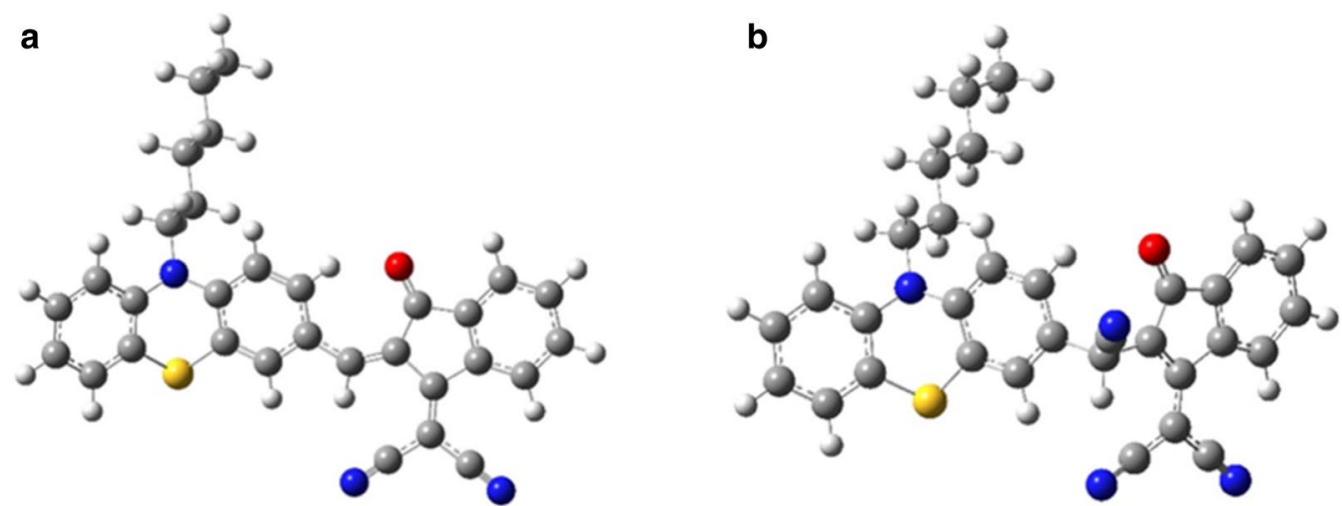

Fig. 12 Optimized structures PTZON (a) and PTZON-CN ${ }^{-}$(b) with B3LYP/6-31G(d) method

Table 1 Vibrational frequency analysis using B3LYP/6-31G(d) method

\begin{tabular}{lll}
\hline Structure & PTZON & PTZON-CN $^{-}$ \\
\hline Assignment & Frequency $\left(\mathrm{cm}^{-1}\right)$ & 1723 \\
$\mathrm{C}=\mathrm{O}$ & 1774 & $(2268-2298)-2350^{*}$ \\
$\mathrm{C} \equiv \mathrm{N}$ & $(2314-2333)$ & \\
\hline
\end{tabular}

The frequency between parenthesis are those for $\mathrm{C}-\mathrm{N}$ bond present in both PTZON and PTZON-CN ${ }^{-}$

The frequency with a asterisk correspond to the added $\mathrm{CN}^{-}$to the PTZON that is why it does not appear in the former one (PTZON)

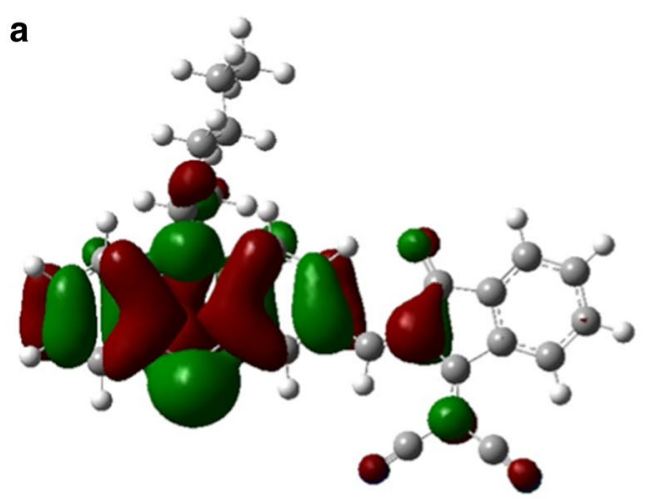

HOMO

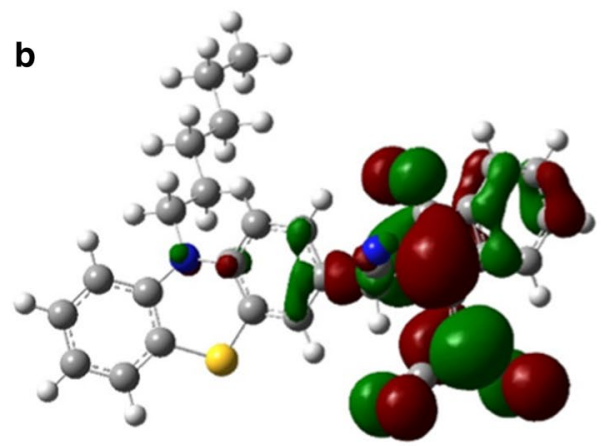

HOMO

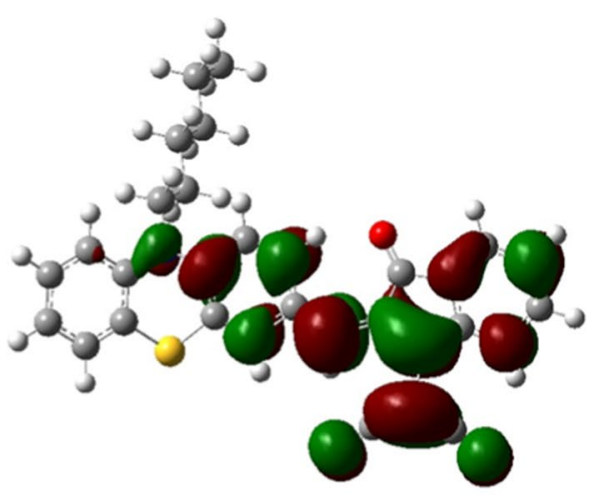

LUMO

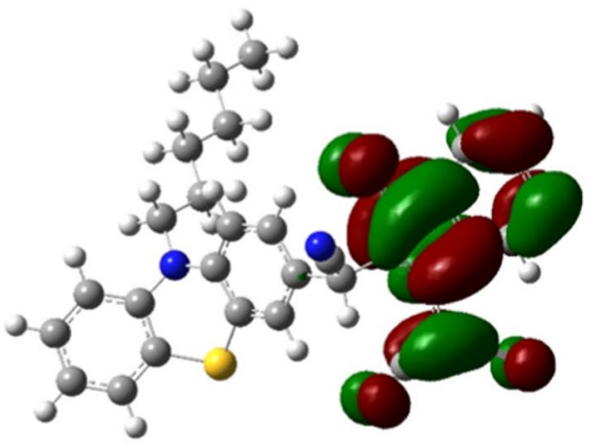

LUMO

Fig. 13 Contour plots of frontier molecular orbitals (isovalue $=0.02$ ) of compound PTZON (a) at the ground state geometry and PTZON-CN $(\mathbf{b})$ at the first excited singlet state geometry 


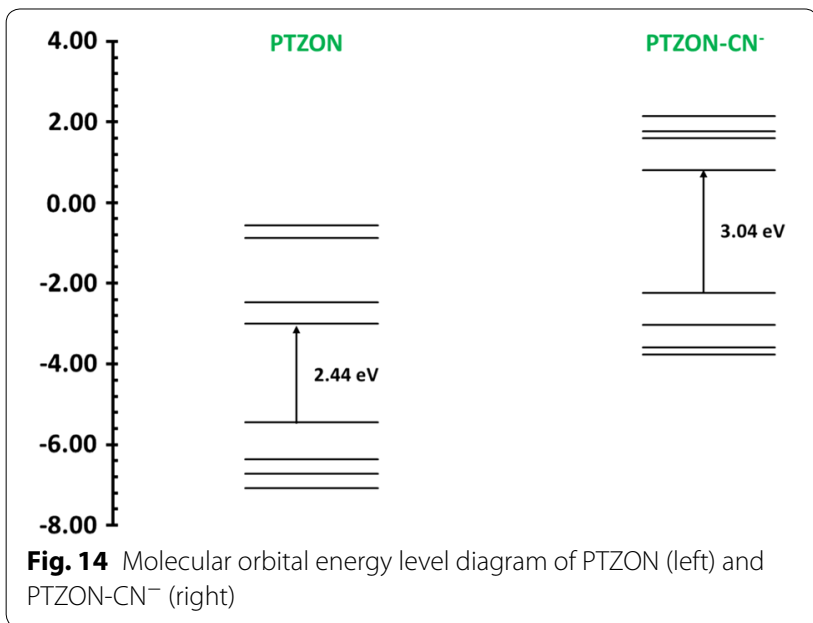

Table 2 Computed absorbance ( $\left.E_{a b s}\right)$ and emission wavelength $\left(\lambda_{\mathrm{abs}}\right)$, oscillator strengths (f) and molecular orbital (MO) compositions for the low-lying excited singlet states of compound PTZON and PTZON-CN ${ }^{-}$

\begin{tabular}{lllll}
\hline State & $\mathbf{E}_{\mathbf{a b s}} / \mathbf{e m}$ & $\boldsymbol{\lambda}_{\mathbf{a b s}} / \mathbf{e m}$ & $\mathbf{f}$ & MO \\
\hline PTZON-S1 & 2.1343 & 580.91 & 0.2915 & $\mathrm{H}-0-->\mathrm{L}+0(98 \%)$ \\
PTZON-S2 & 2.5695 & 482.52 & 0.0671 & $\mathrm{H}-0-->\mathrm{L}+1(96 \%)$ \\
PTZON-S3 & 2.9716 & 417.22 & 0.3952 & $\mathrm{H}-1->\mathrm{L}+0(93 \%)$ \\
PTZON-CN & 2.6879 & 461.26 & 0.1057 & $\mathrm{H}-0->\mathrm{L}+0(99 \%)$ \\
\hline
\end{tabular}

the maximum absorption wavelengths of PTZON and PTZON-CN ${ }^{-}$adduct using the B3LYP functionals and 6-31G(d) basis set. Excellent agreement was obtained between the experimental values of the unbound and bound PTZON and our theoretical simulation values (S19).

\section{Test strip}

As a demonstration for possible practical application, a test strip from TLC was dipped in PTZON solution $\left(10^{-3}\right.$ $\mathrm{M}$ solution in acetonitrile) and air-dried. This process of dipping and air-drying was repeated three times to colorize the strip. Half of the test strip was immersed in aqueous cyanide solution, and the image was taken under UV-lamp for the immersed and non-immersed strip to show the color difference clearly. The demonstrated data prove the suitability of utilizing a simple test strip of PTZON for the fast detection of cyanide anion (Fig. 15).

\section{Conclusion}

A new PTZON chemosensor based-Michael addition mechanism of sensing cyanide anion was synthesized and characterized. PTZON was a turn-off fluorescent

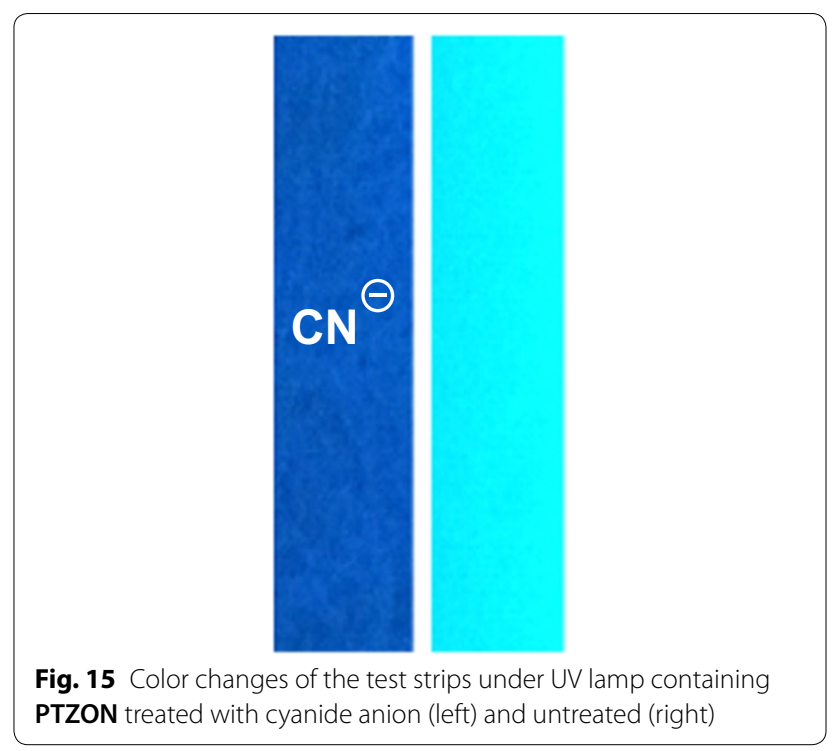

sensor of cyanide anion, and the estimated LOD was $0.011 \mu \mathrm{M}$, which is far lower than the level allowed by WHO $(1.9 \mu \mathrm{M})$. The optical studies, FT-IR spectra, NMR, high-resolution mass, and DFT calculations confirmed the sensing mechanism. A simple test strip demonstrated the suitability of using PTZON with a fast response. Hence, this study introduces a new and simple way for the development of a highly sensitive cyanide sensor viable for application qualitatively by naked-eye detection and quantitatively by fluorescence technique. Further studies are in progress for devising new chemosensors suitable for sensing applications.

\section{Abbreviations}

${ }^{1}$ H NMR: proton nuclear magnetic resonance; ${ }^{13} \mathrm{C}$ NMR: carbon-13 nuclear magnetic resonance; FT-IR: Fourier transform infrared spectroscopy; DFT: density functional theory; FMOs: frontier molecular orbitals; HOMOs: highest occupied molecular orbitals; LUMOs: lowest unoccupied molecular orbitals; ICT: intramolecular charge transfer; UV-VIS: ultraviolet-visible; PTZON: 2-(2-((10-hexyl-10H-phenothiazin-3-yl)methylene)-3-oxo-2,3-dihydroinden1-ylidene) malononitrile; PTZON-CN- : 2-(2-((10-hexyl-10H-phenothiazin-3-yl) methylene)-3-oxo-2,3-dihydroinden-1-ylidene) malononitrile after addition of cyanide anion; DMSO- $\mathrm{d}_{6}$ : deuterated dimethyl sulfoxide; $\mathrm{CH}_{3} \mathrm{CN}$ : acetonitrile; TLC: thin layer chromatography; WHO: world health organization; LOD: limit of detection

\section{Acknowledgements}

Authors sincerely thank the Deanship of Scientific Research at King Khalid University for the support and facilities to conduct this work. The computational work described in this paper was supported by King Abdulaziz University High Performance Computing Center (AZIZ supercomputer, http://hpc.kau.edu.sa).

\section{Declaration}

All authors of the manuscript have read and agreed to its content and are accountable for all aspects of the accuracy and integrity of the manuscript. This article is original, has not already been published in a journal, and is not currently under consideration by another journal. Authors agree to the terms of the BioMed Central Copyright and License Agreement. 


\section{Authors' contributions}

RME suggested the research point and did some of the writing up. FAMA, AMA, AAS, KAM, and carried out the experimental part (preparation and characterization). NSEA performed some of the experimental and language editing. RME and AJ made the computational studies. All authors shared equally the revision of the manuscript. All authors read and approved the final manuscript.

\section{Funding}

This work was supported by the Deanship of Scientific Research at King Khalid University Fund No. R.G.P.1/8/38. All funding bodies played no role in the design of the study and collection, analysis, and interpretation of data and in writing the manuscript.

\section{Availability of data and materials}

The datasets used and/or analysed during the current study are available from the corresponding author on reasonable request.

\section{Competing interests}

The authors declare that they have no competing interests.

\section{Author details}

${ }^{1}$ Chemistry Department, Faculty of Science, King Khalid University, P.O.Box 9004, Abha 61413, Saudi Arabia. ${ }^{2}$ Chemistry Department, Faculty of Science, King Abdulaziz University, P.O. Box 80203, Jeddah 21589, Saudi Arabia. ${ }^{3}$ Dyeing, Printing and Textile Auxiliaries Department, Textile Research Division, National Research Centre, Dokki, Cairo 12622, Egypt. ${ }^{4}$ Center of Excellence for Advanced Materials Research, King Abdulaziz University, Jeddah 21589, Saudi Arabia. ${ }^{5}$ Chemistry Department, Faculty of Science, Umm Al-Qura University, Mecca, Saudi Arabia.

Received: 14 August 2019 Accepted: 17 December 2019

Published online: 07 January 2020

\section{References}

1. Vennesland B, Conn EE, Knownles CJ, Westly J, Wissing F (1981) Cyanide in biology. Academic Press, London

2. Palomares E, Martínez-Díaz MV, Torres T, Coronado E (2006) A highly sensitive hybrid colorimetric and fluorometric molecular probe for cyanide sensing based on a subphthalocyanine dye. Adv Funct Mater 16:1166-1170

3. Anzenbacher P, Tyson DS Jr, Jursiková K, Castellano FN (2002) Luminescence lifetime-based sensor for cyanide and related anions. J Am Chem Soc 124:6232-6233

4. Baskin SI, Brewer TG (1997) Cyanide poisoning. In: Sidell F, Takafuji ET, Franz DR (eds) In medical aspects of chemical and biological warfare. TMM Publication, Washington, DC

5. Kulig KW (1991) Department of health and human services. Cyanide Toxicity, U.S., Atlanta

6. World Health Organization (1996) Guidelines for drinking-water quality. World Health Organization, Geneva

7. Kaim W, Schwederski B, Klein A (2013) Bioinorganic chemistry-inorganic elements in the chemistry of life: an introduction and guide. Wiley, Hoboken

8. World Health Organization (2004) WHO guidelines for drinking-water quality: recommendations. World Health Organization, Geneva

9. Suzuki T, Hiolkin A, Kurahashi M (2003) Development of a method for estimating an accurate equivalence point in nickel titration of cyanide ions. Anal Chim Acta 476:159-165

10. Safavi A, Maleki N, Shahbaazi HR (2004) Indirect determination of cyanide ion and hydrogen cyanide by adsorptive stripping voltammetry at a mercury electrode. Anal Chim Acta 503:213-221

11. Ishii A, Seno H, Watanabe-Suzuki K, Suzuki O (1998) Determination of cyanide in whole blood by capillary gas chromatography with cryogenic oven trapping. Anal Chem 70:4873-4876
12. Timofeyenko YG, Rosentreter JJ, Mayo S (2007) Piezoelectric quartz crystal microbalance sensor for trace aqueous cyanide ion determination. Anal Chem 79:251-255

13. Shan D, Mousty C, Cosnier S (2004) Subnanomolar cyanide detection at polyphenol oxidase/clay biosensors. Anal Chem 76:178-183

14. Isaad J, Achari AE (2011) Colorimetric sensing of cyanide anions in aqueous media based on functional surface modification of natural cellulose materials. Tetrahedron 67:4939-4947

15. Ren J, Zhu W, Tian H (2008) A highly sensitive and selective chemosensor for cyanide. Talanta 75:760-764

16. Cacace D, Ashbaugh H, Kouri N, Bledsoe S, Lancaster S, Chalk S (2007) Spectrophotometric determination of aqueous cyanide using a revised phenolphthalein method. Anal Chim Acta 589:137-141

17. Lee KS, Kim HJ, Kim GH, Shin I, Hong Jl (2008) Fluorescent chemodosimeter for selective detection of cyanide in water. Org Lett 10:49-511702

18. Chung YM, Raman B, Kim DS, Ahn KH (2006) Fluorescence modulation in anion sensing by introducing intramolecular $\mathrm{H}$-bonding interactions in host-guest adducts. Chem Commun 2:186-188

19. Badugu R, Lakowicz JR, Geddes CD (2004) Fluorescence intensity and lifetime-based cyanide sensitive probes for physiological safeguard. Anal Chim Acta 522:9-17

20. Badugu R, Lakowicz JR, Geddes CD (2005) Enhanced fluorescence cyanide detection at physiologically lethal levels: reduced ICT-based signal transduction. J Am Chem Soc 127:3635-3641

21. Jung HS, Han JH, Kim ZH, Kang C, Kim JS (2011) Coumarin-Cu(II) ensemble based cyanide sensing chemodosimeter. Org Lett 13:5056-5059

22. Lee H, Kim HJ (2012) Highly selective sensing of cyanide by a benzochromene-based ratiometric fluorescence probe. Tetrahedron Lett 53:5455-5457

23. Park S, Kim HJ (2010) Highly activated Michael acceptor by an intramolecular hydrogen bond as a fluorescence turn-on probe for cyanide. Chem Commun 46:9197-9199

24. Gong WT, Zhang QL, Shang L, Gao B, Ning GL (2013) A new principle for selective sensing cyanide anions based on 2-hydroxy-naphthaldeazine compound. Sensors Actuators B 177:322-326

25. Xie YS, Ding YB, Li X, Wang C, Hill JP, Ariga K, Zhang WB, Zhu WH (2012) Selective, sensitive and reversible turn-on fluorescent cyanide probes based on 2,2'-dipyridylaminoanthracene-Cu ${ }^{2+}$ ensembles. Chem Commun 48:11513-11515

26. Chen B, Ding YB, Li X, Zhu WH, Hill JP, Ariga K, Xie YS (2013) Steric hindrance-enforced distortion as a general strategy for the design of fluorescence turn-on cyanide probes. Chem Commun 49:10136-10138

27. El-Shishtawy RM, Al-Zahrani FAM, Al-amshany ZM, Asiri AM (2017) Synthesis of a new fluorescent cyanide chemosensor based on phenothiazine derivative. Sensors Actuators B 240:288-296

28. Ramachandran E, Vandarkuzhali SAA, Sivaraman G, Dhamodharan R (2018) Phenothiazine based donor-acceptor compounds with solid state emission in the yellow to NIR region and their highly selective and sensitive detection of cyanide ion in ppb level. Chem Eur J 24:11042-11050

29. Zhou X, Mu W, Lv X, Liu D (2013) Ratiometric fluorescent detection of $\mathrm{CN}^{-}$based on $\mathrm{CN}^{-}$-promoted interruption of $\pi$-conjugation of a coumarin-bearing Michael receptor. RSC Adv 3:22150-22154

30. Zhu YR, Li H, Yan GT, Shi BB, Zhang YM, Lin Q, Yao H, Wei TB (2015) A simple Michael acceptor type quinoline derivative for highly selective sequential recognition of $\mathrm{CN}^{-}$and $\mathrm{Cu}^{2+}$ in aqueous solution. RSC Adv 5:49953-49957

31. Konidena RK, Thomas Justin KR (2014) Selective naked-eye cyanide detection in aqueous media using a carbazole-derived fluorescent dye. RSC Adv 4:22902-22910

32. Rao PG, Saritha B, Rao TS (2019) Highly selective reaction based colorimetric and fluorometric chemosensors for cyanide detection via ICT off in aqueous solution. J Photochem Photobiol A 372:177-185

33. Zhua Y, Wang K, Song W, Dong B, Zhao S, Guan R, Li Z, Sun Y, Cao D (2019) A mitochondria-targeted ratiometric fluorescent probe for endogenous cyanide in biological samples. Sensors Actuators B 294:283-290

34. Guo Z, Hu T, Sun T, Li T, Chi H, Niu Q (2019) A colorimetric and fluorometric oligothiophene-indenedione-based sensor for rapid and highly sensitive detection of cyanide in real samples and bioimaging in living cells. Dyes Pigm 163:667-674

35. Guo Z, Niu Q, Yang Q, Li T, Chi H (2019) A highly selective and sensitive dual-mode sensor for colorimetric and turn-on fluorescent detection 
of cyanide in water, agro-products and living cells. Anal Chim Acta 1065:113-123

36. Niu Q, Sun T, Li T, Guo Z, Pang H (2018) Highly sensitive and selective colorimetric/fluorescent probe with aggregation induced emission characteristics for multiple targets of copper, zinc and cyanide ions sensing and its practical application in water and food samples. Sensor Actuat B 266:730-743

37. Sun T, Niu Q, Li Y, Li T, Hu T, Wang E, Liu H (2018) A novel oligothiophenebased colorimetric and fluorescent "turn on" sensor for highly selective and sensitive detection of cyanide in aqueous media and its practical applications in water and food samples. Sensor Actuat B 258:64-71

38. Niu Q, Lan L, Li T, Guo Z, Jiang T, Zhao Z, Feng Z, Xi J (2018) A highly selective turn-on fluorescent and naked-eye colorimetric sensor for cyanide detection in food samples and its application in imaging of living cells. Sensor Actuat B 276:13-22

39. Lan L, Li T, Wei T, Pang H, Sun T, Wang E, Liu H, Niu Q (2018) Oligothiophene-based colorimetric and ratiometric fluorescence dual-channel cyanide chemosensor: sensing ability, TD-DFT calculations and its application as an efficient solid state sensor. Spectrochim Acta Part A 193:289-296

40. Zayed MEM, El-Shishtawy RM, Elroby SA, Al-Footy KO, Al-amshany ZM (2018) Experimental and theoretical study of donor- $\pi$-acceptor compounds based on malononitrile. Chem Central J 12:26

41. Al-Zahrani FA, Arshad MN, Asiri AM, Mahmood T, Gilani MA, El-Shishtawy RM (2016) Synthesis and structural properties of 2-((10-alkyl-10H-phenothiazin-3-yl)methylene)malononitrile derivatives; a combined experimental and theoretical insight. Chem Central J 10:13

42. El-Shishtawy RM, Elroby SA, Asiri AM, Müllen K (2016) Optical absorption spectra and electronic properties of symmetric and asymmetric squaraine dyes for use in dssc solar cells: DFT and TD-DFT studies. Int J Mol Sci 17:487-495

43. El-Shishtawy RM, Borbone F, Al-Amshany ZM, Tuzi A, Barsella A, Asiri AM, Roviello A (2013) Thiazole azo dyes with lateral donor branch: synthesis, structure and second order NLO properties. Dyes Pigments 96:45-51

44. Lu H, Mack J, Yang Y, Shen Z (2014) Structural modification strategies for the rational design of red/NIR region BODIPYs. Chem Soc Rev 43:4778-4823

45. El-Shishtawy RM (2009) Functional dyes, and some hi-tech applications. Int J Photoenergy 2009:434897

46. El-Shishtawy RM, Al-Zahrani FAM, Afzal SM, Razvi MAN, Al-amshany ZM, Bakry AH, Asiri AM (2016) Synthesis, linear and nonlinear optical properties of a new dimethine cyanine dye derived from phenothiazine. RSC Adv 6:91546-91556

47. El-Shishtawy RM, Decoppet J-D, Al-Zahrani FAM, Cao Y, Khan SB, AlGhamdi MS, Alhogbi BG, Asiri AM, Zakeeruddin SM, Grätzel M (2018) Influence of redox electrolyte on the device performance of phenothiazine based dye sensitized solar cells. New J Chem 42:9045-9050
48. Kafafy H, Wu H, Peng M, Hu H, Yan K, El-Shishtawy RM, Zou D (2014) Steric and solvent effect in dye-sensitized solar cells utilizing phenothiazinebased dyes. Int J Photoenergy 2014:548914

49. Cho MJ, Kim JY, Kim JH, Lee SH, Dalton LR, Choi DH (2005) Heterocyclic nonlinear optical chromophores composed of phenothiazine or carbazole donor and 2-cyanomethylene-3-cyano-4,5,5- trimethyl-2,5-dihydrofuran acceptor. Bull Korean Chem Soc 26:77-84

50. Kohn W, Sham LJ (1965) Self-consistent equations including exchange and correlation effects. Phys Rev 140:A1133

51. Stephens PJ, Devlin FJ, Chabalowski CF, Frisch MJ (1994) Ab initio calculation of vibrational absorption and circular dichroism spectra using density functional force fields. J Phys Chem 98:11623-11627

52. Rassolov VA, Ratner MA, Pople JA, Redfern PC, Curtiss LA (2001) 6-31G* basis set for third-row atoms. J Comp Chem 22:976-984

53. Aziz SG, Osman OI, Elroby SA, Hassan WMI, Jedidi A, Hilal RH (2018) Proton-coupled electron transfer in dye-sensitized solar cells: a theoretical perspective. Struct Chem 29:983-997

54. Yang G, Si Y, Su Z (2011) Theoretical study on the chiroptical optical properties of chiral fullerene $C_{60}$ derivative. J PhysChem A 115:13356-13363

55. Frisch MJ, Trucks GW, Schlegel HB, Scuseria GE, Robb MA, Cheeseman JR, Scalmani G, Barone V, Mennucci B, Petersson GA, Nakatsuji H, Caricato M, Li X, Hratchian HP, Izmaylov AF, Bloino J, Zheng G, Sonnenberg JL, Hada M, Ehara M, Toyota K, Fukuda R, Hasegawa J, Ishida M, Nakajima T, Honda Y, Kitao O, Nakai H, Vreven T, Montgomery JA Jr, Peralta JE, Ogliaro F, Bearpark M, Heyd JJ, Brothers E, Kudin KN, Staroverov VN, Kobayashi R, Normand J, Raghavachari K, Rendell A, Burant JC, lyengar SS, Tomasi J, Cossi M, Rega N, Millam JM, Klene M, Knox JE, Cross JB, Bakken V, Adamo C, Jaramillo J, Gomperts R, Stratmann RE, Yazyev O, Austin AJ, Cammi R, Pomelli C, Ochterski JW, Martin RL, Morokuma K, Zakrzewski VG, Voth GA, Salvador P, Dannenberg JJ, Dapprich S, Daniels AD, Farkas Ö, Foresman JB, Ortiz JV, Cioslowski J, Fox DJ (2009) Gaussian 09, Revision E.01. Gaussian, Inc., Wallingford

56. Skoog DA, Holler FJ, Crouch SR (2007) Principles of instrumental analysis. Brooks/Cole. Thomson Learning, Melbourne

\section{Publisher's Note}

Springer Nature remains neutral with regard to jurisdictional claims in published maps and institutional affiliations.
Ready to submit your research? Choose BMC and benefit from:

- fast, convenient online submission

- thorough peer review by experienced researchers in your field

- rapid publication on acceptance

- support for research data, including large and complex data types

- gold Open Access which fosters wider collaboration and increased citations

- maximum visibility for your research: over $100 \mathrm{M}$ website views per year

At BMC, research is always in progress.

Learn more biomedcentral.com/submissions 